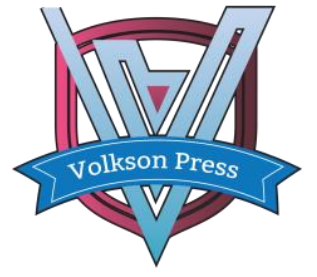

Contents List available at VOLKSON PRESS

Economics \& Management Innovations(EMI)

DOI : http://doi.org/10.26480/icemi.01.2017.94.96

\title{
Using Altman's EM-Score Model to Analyze Bankruptcy: A Case Study of Agribusiness Sector in The Stock Exchange of Thailand
}

\author{
Tidathip Panrod \\ Faculty of Management Science, Silpakorn University, Phetchaburi, Thailand
} tamnarukjung@gmail.com

This is an open access article distributed under the Creative Commons Attribution License, which permits unrestricted use, distribution, and reproduction in any medium, provided the original work is properly cited.

\section{ARTICLE DETAILS}

\section{Article History:}

Received 02 october 2017

Accepted 06 october 2017

Available online 11 october 2017

Keywords:

Agribusiness Sector, Altman's

EM-Score Model, Bankruptcy,

Financial ratios, Stock

Exchange of Thailand

\section{ABSTRACT}

The objectives of this research were 1) to analyze the level of risk (financial distress) in Companies of Agribusiness Sector in The Stock Exchange of Thailand and 2) to study the relationship between financial ratios and the systematic risk ( $\beta$ ) of these firms. The populations were 11 companies of Agribusiness Sector in The Stock Exchange of Thailand. The research presented Altman's EM - Score Model as the research instrument and analyzed the relationship between financial ratios and the systematic risk $(\beta)$ by Pearson's correlation coefficient. The research found that 1) the level of risk in these companies were very low to bankruptcy chance and 2) The relationship between financial ratios and the systematic risk $(\beta)$ was at the medium level. The firm's working capital divided by its total assets, the firm's retained earnings divided by its total assets and the firm's operating income divided by its total assets related to systematic risk $(\beta)$ on the opposite site while the book value of equity divided by its total liabilities related to systematic risk $(\beta)$ on the same way.

\section{Introduction}

Established in late 2015 by the Association of Southeast Asian Nations, the AEC has been seen as a way to promote economic, political, social and cultural cooperation across the region. Thailand needs to be changed because it is an important opportunity.The private sector is considered to be a key contributor to the strategy to prepare for this so, The Thai Chamber of Commerce has formulated seven business strategies, one of the seven business groups that the Thai Chamber of Commerce has focused on Agribusiness sector. Thailand is an agricultural country, despite the socio-economic development in many areas, most of the country's population is still engaged in agricultural occupation especially in the local provinces. According to the National Labor Statistics survey of the National Statistical Office in 2016, 32.9 percent were agriculturist. And the agricultural export sector were major exporters with a total value over 7,548,573 million baht. [8] From the above information, it can be seen that agribusiness is important to the country. This will result in sustainable economic development. Moreover, the economic trend for the agricultural sector in 2017 is expected to grow in the range of $2.4-3.4 \%$, with plant sector $2.6-3.6 \%$, livestock sector $1.1-1.1 \%$, fishery sector $3.0-3.0 \%$ agricultural service $1.5-2.5$ percent and forestry $2.2-3.2$ percent. By the year 2017, Ministry of Agriculture and Cooperatives set the goal to be the year of Changing Towards Smart Agriculture. For the measures, the government officers will operate under the continuous policy. Promote farmer's production by Sufficient Economy Philosophy concept for sustainable growth, manage agribusiness with sciences and technology by the way of integrated knowledge, and include of supporting clean-safetystandard and environmental preservation in production process. All of these will generate growth of agriculture sector in 2017, upgrade its production to the standardization and efficiency, firm farmer's income and a good quality of life. [10] Investments in agribusiness in Thailand are becoming more and more popular nowadays, both small and large companies listed on the stock exchange. Currently, there are 11 listed agribusiness listed companies. Nevertheless, the performance of these companies has decreased continuously since 2011 till now, only two companies with revenue increase. That are United Palm Oil Industry (UPOIC) and Page Seafood Products (TRS). [13] It is interesting to note that such companies may be at risk of bankruptcy. In order to prevent failures and risks, it is necessary to forecast or analyze financial events in advance to prevent damage by EM-score model. This model was developed by Altman, Hartzell and Peck in 1955 based on the Z-Score model, which is suitable for developing countries like Thailand. [4] In this article, EM-Score Model is used to identify the risk status of big companies by studying the relationship between key financial ratios and the Z-score that represent the company's performance in each criteria. The research of Altman's EM-Score Model to Analyze Bankruptcy: A Case Study of Agribusiness Sector in The Stock Exchange of Thailand aims to study the financial performance situation of the high sensitive sector in order to justify that the companies in this sector are in what situation when the economic context change.

\section{Research Objectives}

1. To analyze the level of risk (financial distress) in Companies of Agribusiness Sector in The Stock Exchange of Thailand.

2. To study the relationship between financial ratios and the systematic risk $(\beta)$ of the companies.

3. Scope of the study

\section{Information scope:}

The financial ratios were calculated from financial statement of the Company of Agribusiness Sector in the Stock Exchange of Thailand that the populations consisted of 11 companies.

\section{Variable scope:}

Dependent Variables are risk (Probability of bankruptcy) that calculated by Altman's EM -Score Model and Systematic Risk (回) that calculated from the data of the Stock Exchange of Thailand and Bank of Thailand.

Independent Variables are four financial ratios in Altman's EM-Score Model. The ratios are listed below:

working capital/total assets retained earnings/total assets operating income/total assets book value of equity/total liabilities. 


\section{Time scope:}

The study period are 2 years from Q4, 2014 to Q3, 2016 whilst Thailand economic situation stayed on downtrend

\section{Conceptual Framework of the Study}

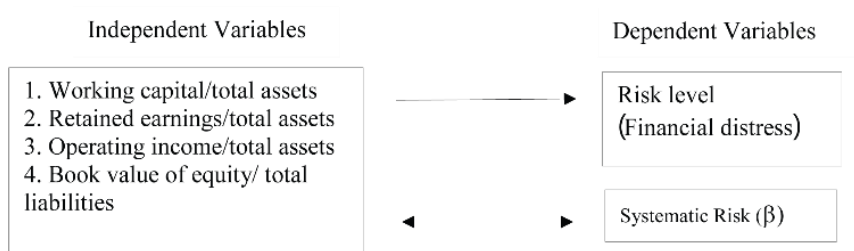

Fig. I. The conceptual framework

\section{Literature References}

Altman [2] introduced EM- Score Model that revised Altman's z - score model to incorporate a four variable $\mathrm{z}$ - score prediction model. He felt this revised model significantly improved the predictive ability of his model and made it simpler to incorporate. Then Altman [3] studied a scoring system (EMS Model) for Emerging Corporate Bonds. The EMS Model can be applied to non-manufacturing companies, and manufacturers, and is relevant for privately held and publicly owned firms. The next study confirmed by Muminovic, Pavlovic and Cvijanovic [12] in Predictive Ability of Various Bankruptcy Prediction Z-Score Models for Serbian Publicly Listed Companies. Prediction accuracy was tested for three Zscore variation: Altman's original model, a revised model for private companies, and the EMS model.

For studying in Thailand case, Khemnguad [4] researched the Study of Precision and Altman's EM-Score Model Development for Financial Failure Forecasting in Stock Exchange of Thailand. Then Meeampol et. al. [11] applied EM Z-Scored Model in Predict Bankruptcy: A Case Study of Listed Companies in The Stock Exchange of Thailand (SET).

\section{Research Methodology}

\section{Source of information}

Secondary data used in financial ratios calculating come from balance sheet and income statement of Agribusiness sector companies from Q4, 2014 to Q3, 2016. These data was collected from the websites of Stock Exchange of Thailand. The information of systematic risk $(\beta)$ was collected from websites of Bank of Thailand and the websites of Stock Exchange of Thailand.

\section{Data analysis}

- To analyze the level of risk (financial distress) this study used Altman's EM - Score Model. The model assigns a firm a $\mathrm{z}$ - score derived from 4 weighted variables:

$\mathrm{z}=3.25+6.56 X_{1}+3.26 X_{2}+6.72 X_{8}+1.05 X_{4}$

where $X_{1}=$ working capital/total assets; $X_{2}=$ retained earnings $/$ total assets;

$X_{2}=$ operating income/total assets; $X_{4}=$ book value of equity/total liabilities.

The final number of the $\mathrm{z}$-score $<1.1$ have a high probability of bankruptcy or distress zone, while z-scores $>2.6$ represent financial soundness or safe zone. The gray zone of ignorance exists when firms have $\mathrm{z}$-score between 1.1 and 2.6

- To study the relationship between financial ratios and the systematic risk $(\beta)$ use financial ratios from Altman's Z-Score model and systematic risk ( $\beta$ ) calculated from Capital Asset Pricing Model (CAPM), that describes the relationship between risk and expected return that used in pricing for risky securities.

Here is the formula:

$E\left(R_{i}\right)=R_{f}+\beta_{i}\left(E\left(R_{m}\right)-R_{f}\right.$
Where:

$E\left(R_{\mathrm{i}}\right)=$ Expected return

$R_{\mathrm{f}}=$ Risk free rate (Government bond)

$E\left(R_{m}\right)=$ Expected market return

$\beta_{\mathrm{i}}=$ Systematic risk (Change in each security return when market return change or $\Delta \mathrm{R}_{\mathrm{i}} / \Delta \mathrm{R}_{\mathrm{m}}$ )

The relationship between financial ratios and systematic risk $(\beta)$ was analyzed by Pearson's correlation coefficient.

\section{Results}

\section{The level of risk (financial distress) in Agribusiness sector} companies in the Stock Exchange of Thailand.

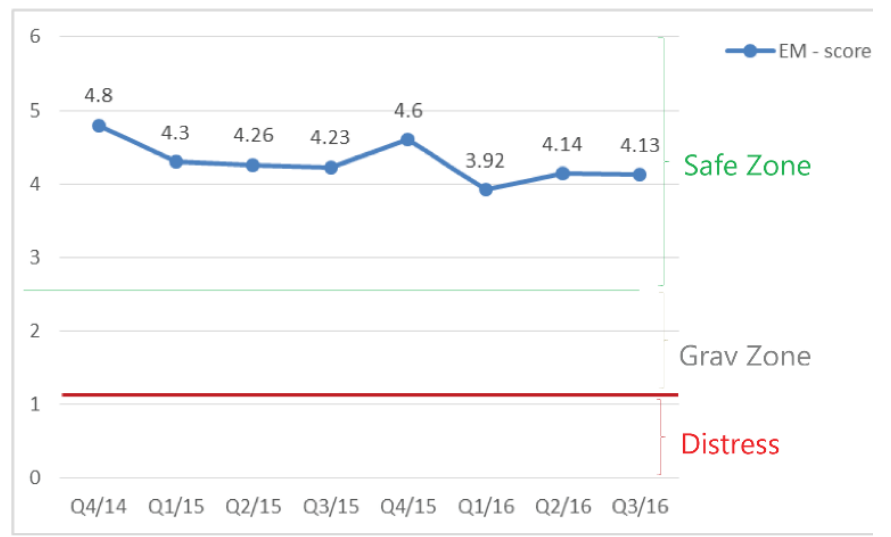

Fig. 2: Level of risk (financial distress) in Agribusiness sector in the Stock Exchange of Thailand

The result showed that the EM Z-score decreased slightly during the fourth quarter of 2014 and the third quarter of 2016. However, most of them stayed above 2.6 that meant financial soundness or safe zone. On the other hand, the EM Z-score in Agribusiness sector of Thailand has not go through the Distress zone (score <1.1). The lowest score was 3.92 in the first quarter of 2016. Thus, the risk in this sector was very low to bankruptcy in conclusion due to maintaining their performance under official regulation.

\section{The relationship between financial ratios and the systematic risk ( $\beta$ ).}

$X_{1}$ (Working capital/total assets) related to systematic risk $(\beta)$ at 0.61 on the opposite site.

$X_{2}$ (Retained earnings/total assets) related to systematic risk $(\beta)$ at 0.38 on the opposite site.

$X_{3}$ (Operating income/total assets) related to systematic risk $(\beta)$ at 0.29 on the opposite site.

$X_{4 \text { (Book value of equity/total liabilities) related to systematic risk }(\beta) \text { at }}$ 0.22 on the same way.

\section{Discussion}

1. The level of risk (financial distress) in Agribusiness sector companies in the Stock Exchange of Thailand.

From the research result showed that there was a little chance for Bankruptcy in this sector, however it occurred as a result of using big firms performance and all of these must operate under the Stock Exchange of Thailand regulations, then the financial statement assumed to reflect their operation are quite well.

In addition to, the increasing price of agriculture products from Q1 2016 result to higher export volumes and performance of the relevant companies including this group sector in The Stock Exchange of Thailand. [8]

2. The relationship between financial ratios and the systematic risk ( $\beta$ ) of Agribusiness sector.

Working capital/total assets that is a measure of liquid assets in relation to the firm's size. The difference between current liabilities represents 
working capital. A positive working capital indicates a firm's ability to pay its bills. A business entity with a negative working capital will experience difficulty meeting its obligations [4] Thus, this ratio related to systematic risk on the opposite site.

Retained earnings/total assets represents a measure of cumulative profitability reflecting the firm's age as well as its earning power. A history of profitable operations and reduced debt is signified by firms that retain earnings or reinvest operational profits. Low retained earnings may indicate a poor business year or reduced longevity for the firm [3]; as a result, this ratio related to systematic risk on the opposite site.

Operating income/total assets is a measure of an organization's operating efficiency separated from any leverage effects that is a true depiction of asset production. This ratio estimates cash supply available for allocation to creditors, the government and shareholders [4]. So for that reason, this ratio related to systematic on the opposite site.

The last ratio, book value of equity divided by its total liabilities. The stock market, the primary estimate of firm's worth, suggests that price changes may foreshadow pending problems if a firm's liabilities exceed its assets that ratio is a more effective financial distress predictor than net worth /total debt [3],[4]. Thus, this ratio related to systematic risk on the same way.

\section{Conclusion and Recommendation}

\section{Conclusion}

The research paper summarized that the risk in Agribusiness sector in the Stock Exchange of Thailand showed very low risk to bankruptcy from the result calculation on Altman's EM - Score Model. The relationship between financial ratios and the systematic risk showed that the firm's working capital divided by its total assets, the firm's retained earnings divided by its total assets, the firm's earnings before interest and taxes divided by its total assets and the firm's sales divided by its total assets related to systematic risk $(\beta)$ on the opposite site, except the market value of the firm's equity and preferred stock divided by its liabilities related to systematic risk $(\beta)$ on the same way.

\section{Recommendations}

The research recommendations have showed only the bankruptcy situation of the Agribusiness sector in Stock Exchange of Thailand, but when using the research results for security investment, the investors must consider the forecasting model of the Agribusiness sector with others related factors such as social and economic environments, timing for investment and the fundamental analysis of each firm before investment decision making. Moreover, next study should compare another model with Altman's EM - Score model for efficiency forecasting risk level in any sector. In the long-run, the research should concentrate on studying the suitable Altman's EM - Score model by adapting Model for Thailand context.

\section{Acknowledgement}

Thanks for impression and cooperation from all of the informant sources. If this research is worth to the society, the researcher would dedicate this worthiness to all grateful and respectful related people. However, any mistakes happened in this research, the researcher would like to accept humbly and apologize for any inconvenience.

\section{References}

[1] Bank of Thailand, Report on Agricultural Products 2014 - 2015 Information

on https://www.bot.or.th/Thai/MonetaryPolicy/NorthEastern/Doclib_Com modityYearly/ final.pdf]

[2] E. I. Altman, Corporate Financial Distress and Bankruptcy. 2nd edition. John Wiley \& Sons, New York (1993)

[3] E.I. Altman, An Emerging Market Credit Scoring System for Corporate Bonds, Emerging Market Review, Vol. 10, no. 6 (2005), pp. $311-323$

[4] E. Khemnguad, The Study of Precision and Altman's EM-Score Model Development for Financial Failure Forecasting in Stock Exchange of Thailand, Thesis of MBA. Bangkok University, (2011)

[5] G. Bonazzi and M. Iotti, Agricultural Cooperative Firms: Budgetary Adjustments and Analysis of Credit Access Applying Scoring Systems, American Journal of Applied Sciences, Vol. 11, no. 7 (2014), pp. 1181 1192

[6] M. Salehi, and B. Abedini, Financial Distress Prediction in Emerging Market: Empirical Evidences from Iran, Business Intelligence Journal, Vol. 2, no. 2 (2009), pp. $398-409$

[7] National Statistical Office Thailand, The work of Thai people in 2016 Information on http://service.nso.go.th/nso/nsopublish/ reportJun.pdf

[8] Office of Agricultural Economics, The value of major agricultural Products exports. Information http://www.oae.go.th/oae report/export import/exp

[9] Siam Commercial Bank, Top 10 Import - Export Thailand in 2016 Information on https://scbsme.scb.co.th/sme-inspirationdetail/import

[10] S. Jariya, The agricultural economy in 2016 Information on http://www.kasetkaoklai.com/home/2016/12/

[11] S. Meeampol, P. Lerskullawat, A. Wongsorntham, P. Srinammuang, V. Podpetch, and R. Noonoi, Applying Emerging Market Z - Score Model to Predict Bankruptcy: A Case Study of Listed in The Stock Exchange of Thailand (SET), Proceeding Management, Knowledge and Learning International Conference (2014), pp. 1227- 1237

[12] S. Muminovic, V. Pavlovic and J. M. Cvijanovic, Predictive Ability of Various Bankruptcy Prediction Z - Score Models of Serbian Publicly Listed Companies, UDK., Original Scientific Paper, Vol. 38, no. 3 (2011), pp. 15 27

[13] S. Sudjawongrasamee and W. Banchuenvijit, "Economic Factors Affecting the Stock Price of Agribusiness in The Stock Exchange of Thailand," Journal of Finance, Banking and Investment, Vol. 1, no. 2 (2014), pp. $56-71$

[14] The Stock Exchange of Thailand, Summary of Agribusiness Performance, Information on https://marketdata.set.or.th/ $\mathrm{mkt} / \mathrm{sectorialindices.do}$

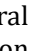
on 